\title{
Reducing the Prevalence of Catheter-Related Infections by Quality Improvement: Six-Year Follow-Up Study
}

\author{
Dan Malm 1,2,3* , Bo Rolander3,4, Eva-Marie Ebefors'2, Lisa Conlon1,3, Annette Nygårdh1 \\ ${ }^{1}$ Department of Nursing, School of Health and Welfare, Jönköping University, Jönköping, Sweden \\ ${ }^{2}$ Department of Internal Medicine, County Hospital Ryhov, Jönköping, Sweden \\ ${ }^{3}$ Futurum Academy for Healthcare, Jönköping, Sweden \\ ${ }^{4}$ Department of Behavioral Science and Social Work, School of Health and Welfare, Jönköping University, \\ Jönköping, Sweden \\ Email: "Dan.Malm@ju.se
}

Received 23 December 2015; accepted 13 February 2016; published 16 February 2016

Copyright (C) 2016 by authors and Scientific Research Publishing Inc.

This work is licensed under the Creative Commons Attribution International License (CC BY).

http://creativecommons.org/licenses/by/4.0/

cC) (7) Open Access

\begin{abstract}
Background: Peripheral venous catheter (PVC) insertion is a crucial nursing action during life support. Several factors that increase the risk of thrombophlebitis associated with PVCs have been reported. Objective: We wish to evaluate the impact of a quality improvement regarding PVC treatment for patients with coronary heart diseases. Method: A longitudinal, quantitative observational study was carried out in 2008 and 2013 in a hospital in southern Sweden with 360 consecutive patients suffering from acute chest pain. New routines for PVC treatment were included in the hospital with daily inspection according to a checklist. A structured observation protocol was used to survey the prevalence of thrombophlebitis between 2008 and 2013. Also, we examined the relationship between the location and luminal diameters of PVCs. Results: The student's $t$-test showed significant differences between 2008 and 2013 with respect to luminal diameter of PVCs $(p=0.002)$, prevalence of thrombophlebitis $(p=0.003)$ and number of days with PVC left in situ ( $\mathrm{p}<0.001)$. Conclusion: These findings emphasize the value of using systematic daily inspections and checklists to achieve quality and safety in patients with acute chest pain having PVC-based treatment.
\end{abstract}

\section{Keywords}

Bloodstream Infection, Peripheral Venous Catheter, Quality Improvement, Thrombophlebitis

\footnotetext{
${ }^{*}$ Corresponding author.
}

How to cite this paper: Malm, D., Rolander, B., Ebefors, E.-M., Conlon, L. and Nygårdh, A. (2016) Reducing the Prevalence of Catheter-Related Infections by Quality Improvement: Six-Year Follow-Up Study. Open Journal of Nursing, 6, 79-87. 


\section{Introduction}

Insertion of a peripheral venous catheter (PVC) is a crucial nursing action during life support in emergency (prehospital or hospital) settings for patients with symptoms of acute myocardial infarction. In hospitalized patients, administration of pharmaceutical substances via the intravenous route is the most common invasive procedure [1] [2].

Risks associated with intravenous therapy include thrombophlebitis (prevalence of $2.3 \%-35 \%$ ) and intravenous catheter-related bacterial infection $(\approx 0.8 \%)$ [3]. Major differences in studies reporting the prevalence of thrombophlebitis may be due (at least in part) to differences in: survey selection; follow-up times; definitions of thrombophlebitis. An acceptable prevalence of thrombophlebitis is $\leq 5 \%$ but higher levels are acceptable if a PVC is inserted by paramedics [4] [5]. Anderson et al. show that, for patients receiving medication that excite peripheral vessels, elective changing of intravenous PVCs results in marked reduction in the prevalence of peripheral venous thrombophlebitis [6]. Recent studies have shown that re-siting PVCs (if indicated clinically) does not lead to more complications or reduced healthcare costs compared with changing such PVCs routinely every $72 \mathrm{~h}$ [7]-[9]. However, guidelines recommend that PVCs should be re-sited every 48 - $96 \mathrm{~h}$ in adults. This strategy has been shown to restrict the risk of infection, and most hospitals follow this recommendation [10] [11]. In a review conducted by the Cochrane Collaboration in 2015, there was no evidence to support re-siting of PVCs every 72 - $96 \mathrm{~h}$ to minimize the risk of bacterial infections and phlebitis [12] [13]. In addition, guidelines state that ongoing, close monitoring of the cannula site, along with timely treatment, will help to identify complications. However, those guidelines cite only one study [14] to support this recommendation. Hence, consensus regarding current use of PVC is lacking.

\subsection{Problems at a County Hospital in Southern Sweden}

Evidence-based PVC treatment results in reduced risks for patients and excessive healthcare costs [9] [12] [15]. However, guidelines are based on incongruous literature and emphasize the duration of PVC-based treatment. Daily observation as well as documentation of puncture sites and luminal diameter may provide more relevant information [10].

In the Swedish healthcare system, nurses are responsible for informing patients why PVCs need to be inserted, as well as their maintenance, removal and documentation. Each year in Sweden, nurses insert $\approx 5$ million PVCs [16]. Such everyday tasks necessitate considerable demands on knowledge and skills. All nursing students in Sweden undergo education and training on PVC insertion.

The present study took place in County Hospital in southern Sweden. Ward review revealed that $\approx 6 \%-10 \%$ of patients at County Hospital had suffered from infections that could lead to thrombophlebitis upon PVC-based treatment. Therefore, it was decided at the departmental level to work with quality improvements (QIs) for nurses regarding PVC management.

\subsection{Intended Improvement}

The intended improvement was to reduce the prevalence of bacterial infections and phlebitis. To achieve improvements in PVC-based treatment, efforts from healthcare professionals are needed [17]. Systems analyses of adverse events [18] have emphasized that the intended outcome can be achieved if healthcare professionals and patients collaborate to obtain quality and safety in healthcare (Table 1). Patients should also follow guidelines for identification of the symptoms of thrombophlebitis (redness or swelling) and report them to nurses. An additional intended outcome was to investigate the prevalence of thrombophlebitis in patients with chest pain who received paramedic care. In addition, to improve outcome, systematic data-guided activities were carried out [19].

\subsection{Quality Improvement}

Quality Improvement (QI) is being adopted increasingly in healthcare in Sweden and overseas. In the present study, a QI method, root cause analysis (RCA) [20] [21], was used to identify and understand in a systematic way the underlying reasons why a problem or error occurs. RCA is important for the prevention of injuries and errors in healthcare [22]. Evidence regarding the improvement and successful outcomes desired from healthcare professionals is lacking [23] [24]. Consequently, evaluation of improvement interventions regarding the safety 
of PVC-based treatment will be useful for healthcare professionals [18] [23] [25]. Therefore the aim of this study was to evaluate the impact of QI regarding PVC-based treatment for patients with coronary heart diseases.

\section{Materials and Methodology}

\subsection{Study Design and Selection Criteria}

This was a longitudinal, quantitative, observational study carried out in 2008 and 2013 at a surgical and medical clinic in County Hospital in South of Sweden. A total of 360 (2008: $n=145 ; 2013: n=215)$ consecutive patients with symptoms of chest pain admitted to the Emergency Ward and then transported immediately to the Department of Cardiac Diseases where enrolled in the study.

\subsection{Improvement Intervention}

QI was initiated by a development leader after review of the prevalence of thrombophlebitis on the ward. Using local data and discussion of the prevalence with those involved can lead to deeper understanding of local problems [20]. To analyze the cause of thrombophlebitis, the development leader interviewed nurses and asked three main questions: "What happened?", "How did it happen?" and "Why did it happen?" Information obtained during the interview regarding contributory factors (as perceived by the nurses) was used to improve the routines of safe PVC-based treatment. New routines included daily inspection according to a checklist (Table 2) and re-siting the PVC every third day (or more often if necessary) (Table 1). If drugs that irritated blood vessels were administered, then the PVC was re-sited each day. In conjunction with PVC insertion, nurses rinsed the PVC with $10 \mathrm{~mL}$ of physiologic $(0.9 \%)$ sodium chloride $(\mathrm{NaCl})$. After each injection, the PVC was flushed with $10 \mathrm{~mL}$ of $\mathrm{NaCl}$. The PVC was flushed every day with $10 \mathrm{~mL}$ of $\mathrm{NaCl}$. Step-by-step improvement interventions (Table 3) involved all nurses on the ward.

\subsection{Data Collection}

A structured observational protocol was used for data collection (Table 2). All PVCs were inserted by prehospital paramedics from ambulances (the first PVC or ("PVC1") and by healthcare professionals from the Department of Cardiac Diseases (second, third and fourth PVC ("PVC2", "PVC3" and "PVC4", respectively). All patients were followed up from the insertion to removal of PVCs. Sex and age of patients were taken from individual patient records. Also, how long the catheter was in situ, as well as its diameter and location, were recorded. In accordance with Swedish guidelines for regular changing of PVCs to prevent thrombophlebitis [26], we observed PVC sites for 12 - 72 h [2] [26]. Only specialist nurses made the observations (Table 1), and made assessments according to criteria for thrombophlebitis classification. Each PVC location was observed every day after 12, 24, 48 and $72 \mathrm{~h}$ (Table 2). If redness (grade $>1$ ) or further signs of thrombophlebitis were observed, the PVC was removed. In patients without signs of thrombophlebitis, the PVC were removed or replaced after $72 \mathrm{~h}$.

If a complication was noted, observation of symptoms continued after PVC removal until the patient was asymptomatic. If complications remained after discharge from hospital, or symptoms recurred, patients were requested to visit their general practitioner.

\subsection{Ethical Considerations}

The study followed the principles outlined in the Declaration of Helsinki, and was approved by the Ethics Committee [27]. Eligible patients were given information about the study, and informed consent was obtained from all patients.

\subsection{Statistical Analyses}

Background variables are presented as the mean, 95\% confidence interval (95\% CI), frequency, and percentage. Comparisons between categorical variables in 2008 and 2013 were made with the chi-squared test. But when more than 20 percent of the cells had an expected value less than five have instead Fisher's exact test been used. Bootstrapping was used to calculate 95\% CIs. Analysis of crosstabs with more than four cells have also Correspondence analysis have been used [28]. For variables on scale levels (e.g., PVC 1-4, age) the independent sam- 
Table 1. Guideline for symptoms of thrombophlebitis and interventions for PVCs.

\begin{tabular}{|c|c|c|c|}
\hline Degree & & Symptom of thrombophlebitis & Intervention for PVC \\
\hline 0 & No complication & $\begin{array}{l}\text { No discomfort or slight discomfort; tenderness upon } \\
\text { insertion. }\end{array}$ & No action. \\
\hline 1 & $\begin{array}{l}\text { Slight } \\
\text { thrombophlebitis }\end{array}$ & Redness and tenderness $<15 \times 15$ mm. & $\begin{array}{l}\text { Stop treatment and remove the PVC. } \\
\text { Hirudoid }{ }^{\circledR} \text { ointment applied one to several } \\
\text { times daily. }\end{array}$ \\
\hline 2 & $\begin{array}{l}\text { Medium } \\
\text { thrombophlebitis }\end{array}$ & $\begin{array}{l}\text { Redness, tenderness pain, swelling > } 15 \times 25 \mathrm{~mm} \text {; } \\
\text { increased temperature in the area. }\end{array}$ & $\begin{array}{l}\text { Stop treatment and remove the PVC. } \\
\text { Hirudoid }{ }^{\circledR} \text { ointment applied one to several } \\
\text { times daily. Inform the attending physician. }\end{array}$ \\
\hline 3 & $\begin{array}{l}\text { Severe } \\
\text { thrombophlebitis }\end{array}$ & $\begin{array}{l}\text { Redness, tenderness pain, swelling }>25 \times 50 \mathrm{~mm} \text {; } \\
\text { increased temperature in the area and palpable cord in } \\
\text { the vein. }\end{array}$ & $\begin{array}{l}\text { Stop treatment and remove the PVC. Inform } \\
\text { the attending physician. }\end{array}$ \\
\hline 4 & $\begin{array}{l}\text { Very severe } \\
\text { thrombophlebitis }\end{array}$ & $\begin{array}{l}\text { Redness, pain, swelling more than } 50 \times 50 \mathrm{~mm} \text {; } \\
\text { increased temperature in the area and palpable cord in } \\
\text { the vein; pain spreading up to the arm; possible fever }\end{array}$ & $\begin{array}{l}\text { Stop treatment and remove the PVC. Inform } \\
\text { the attending physician. }\end{array}$ \\
\hline
\end{tabular}

Modified checklist from Lundgren et al., 1993 [30].

Table 2. Checklist for PVC insertion.

\begin{tabular}{ccccccc}
\hline PVC in & PVC & Flush & Flush & PVC out & Thrombophlebitis & Complications \\
\hline Date & Size & Date & Date & Date & Intervention \\
Clock: & Place & /Sign & /Sign & Clock: & /Sign & /Sign \\
/Sign & /Sign & & & & \\
\hline
\end{tabular}

Table 3. Improvement intervention.

\begin{tabular}{|c|c|}
\hline Intervention & Process \\
\hline $\begin{array}{l}\text { To improve the way to PVC-based } \\
\text { treatment is carried out }\end{array}$ & $\begin{array}{l}\text { *A comprehensive review of international and national literature on PVC treatment was done } \\
{ }^{*} \text { A checklist was composed based on the review } \\
{ }^{*} \text { Secure assessment of thrombophlebitis by defining the extent of thrombophlebitis } \\
{ }^{*} \text { Information for all staff on the ward for people with heart disease using the new guideline }\end{array}$ \\
\hline $\begin{array}{l}\text { To test and evaluate compliance to the } \\
\text { checklist }\end{array}$ & $\begin{array}{l}\text { *Follow-up of } 60 \text { patients was conducted } \\
\text { *Nurses' documentation and comments regarding the new working process was reviewed }\end{array}$ \\
\hline $\begin{array}{l}\text { To improve the checklist further and } \\
\text { working practices }\end{array}$ & $\begin{array}{l}{ }^{*} \text { Meetings with nurses where follow-up was discussed } \\
{ }^{*} \text { Create conditions to facilitate compliance with the new guideline. The checklist included } \\
\text { equipment for appropriate PVC-based treatment. }\end{array}$ \\
\hline $\begin{array}{l}\text { To establish the new guideline as a } \\
\text { routine }\end{array}$ & *Follow-up of working practices as a regular discussion at monthly meetings \\
\hline To secure the quality of the new routine & ${ }^{*}$ Continuous follow-up of the checklist \\
\hline
\end{tabular}

ple $t$-test was used. However, none of these variables had a normal distribution according to KolmogorovSmirnov and Shapiro-Wilk tests ( $<$ 0.05). Therefore, a non-parametric test and Mann-Whitney U-test were also used. Both tests reported significant and non-significant variables, so only p values for the independent sample $t$-test are reported. Significance was set at $\alpha=0.05$. Statistical analyses were made using SPSS v22 (IBM, Armonk, NY, USA).

\section{Results}

QI on the ward resulted in significant reductions in the prevalence of complications associated with PVC-based treatment by healthcare professionals (PVC 2-4) in 2013 compared with those in 2008 (p = 0.04). Upon treatment by paramedics (PVC1), the prevalence of complications increased significantly $(p=0.03)($ Table 4$)$. In both groups, the number of days that the PVC was in situ (Table 5) increased significantly $(\mathrm{p}=0.001)$ from a mean of 2.1 days in 2008 to 2.5 days in 2013. There is a significant difference $(p=0.002)$ between 2008 and 2013 with regard to luminal diameter, complications, and days the PVC was left in situ (Table 4, Table 5). Correspondence analyses showed that at PVC1, a blue PVC (lumen diameter, $0.9 \mathrm{~mm}$ ) gave the strongest con- 
Table 4. Distribution of PVCs with location, luminal diameter and complications for 2008 and 2013.

\begin{tabular}{|c|c|c|c|c|c|c|c|c|}
\hline & & \multicolumn{3}{|c|}{2008} & \multicolumn{4}{|c|}{2013} \\
\hline & & $\mathbf{n}$ & $\%$ & $95 \%$ CI & n & $\%$ & $95 \%$ CI & $\mathbf{p}$ \\
\hline \multirow{5}{*}{$\begin{array}{l}\text { Location of PVC1 } \\
\text { (paramedics) }\end{array}$} & Upper hand & 57 & 41.9 & $33.8-50.0$ & 86 & 41.5 & $35.3-48.3$ & \multirow{5}{*}{0.96} \\
\hline & Forearm & 57 & 41.9 & $33.8-50.0$ & 85 & 41.1 & $34.8-47.8$ & \\
\hline & Antecubital & 22 & 16.2 & $10.3-22.8$ & 36 & 17.4 & $12.6-22.7$ & \\
\hline & Neck & - & - & - & - & - & - & \\
\hline & Legs & - & - & - & - & - & - & \\
\hline \multirow{5}{*}{$\begin{array}{c}\text { Location of } \\
\text { PVC2-4 } \\
\text { (healthcare } \\
\text { professionals) }\end{array}$} & Upper hand & 16 & 20.3 & $11.4-29.1$ & 28 & 20.3 & $13.8-26.8$ & \multirow{5}{*}{0.08} \\
\hline & Forearm & 30 & 38.0 & $27.8-42.4$ & 69 & 50.0 & $42.0-58.0$ & \\
\hline & Antecubital & 30 & 38.0 & $26.6-48.1$ & 41 & 29.7 & $22.5-37.7$ & \\
\hline & Neck & 1 & 1.3 & 0 - 3.8 & - & - & - & \\
\hline & Legs & 2 & 2.5 & $0-6.3$ & - & - & - & \\
\hline \multirow{4}{*}{$\begin{array}{l}\text { Luminal diameter } \\
\text { (mm) PVC1 } \\
\text { (paramedics) }\end{array}$} & Yellow (0.7) & 1 & 0.7 & $0-2.1$ & - & - & - & \multirow{4}{*}{0.002} \\
\hline & Blue (0.9) & 44 & 31.2 & $23.4-39.0$ & 35 & 16.9 & $11.6-22.0$ & \\
\hline & Pink (1.1) & 89 & 63.1 & $54.6-70.9$ & 147 & 71.0 & $64.7-77.3$ & \\
\hline & Green (1.3) & 7 & 5.0 & $2.1-9.2$ & 25 & 12.1 & $7.7-16.4$ & \\
\hline \multirow{4}{*}{$\begin{array}{l}\text { Luminal diameter } \\
\text { (mm) PVC 2-4 } \\
\text { (healthcare } \\
\text { professionals) }\end{array}$} & Yellow (0.7) & 1 & 1.3 & $0-5.1$ & - & - & & \multirow{4}{*}{0.07} \\
\hline & Blue (0.9) & 18 & 22.8 & $13.9-32.9$ & 16 & 11.7 & $6.6-16.8$ & \\
\hline & Pink (1.1) & 54 & 68.4 & $58.2-78.5$ & 96 & 70.1 & $62.8-77.4$ & \\
\hline & Green (1.3) & 6 & 7.6 & $2.5-12.7$ & 25 & 18.2 & $12.4-24.8$ & \\
\hline \multirow{2}{*}{$\begin{array}{l}\text { Complications PVC1 } \\
\text { (paramedics) }\end{array}$} & No thrombophlebitis & 143 & 97.9 & $95.2-100$ & 176 & 92.6 & $88.9-96.3$ & \multirow{2}{*}{0.03} \\
\hline & Thrombophlebitis & 3 & 2.1 & 0 - 4.8 & 12 & 7.4 & $3.7-11.1$ & \\
\hline \multirow{2}{*}{$\begin{array}{c}\text { Complications PVC } \\
2-4 \\
\text { (healthcare }\end{array}$} & No thrombophlebitis & 50 & 87.7 & $78.9-94.7$ & 83 & 96.5 & $91.9-100$ & \multirow{2}{*}{0.04} \\
\hline & Thrombophlebitis & 7 & 12.3 & $5.3-21.1$ & 3 & 3.5 & 0 - 8.1 & \\
\hline
\end{tabular}

First PVC (PVC1), second PVC (PVC2), third PVC (PVC3), fourth PVC (PVC4) and age in years for 2008 and 2013 in terms of number (n), percentage (\%), $95 \%$ confidence interval (95\% CI) and probability (p).

Table 5. Sex, age, and number of days PVC left in situ for 2008 and 2013.

\begin{tabular}{|c|c|c|c|c|c|c|c|c|}
\hline & & \multicolumn{3}{|c|}{2008} & \multicolumn{4}{|c|}{2013} \\
\hline & & $\mathbf{n}$ & $\%$ & $95 \% \mathrm{CI}$ & $\mathbf{n}$ & $\%$ & $95 \%$ CI & $\mathbf{p}$ \\
\hline & Female & 65 & 44.5 & $36.3-52.7$ & 80 & 38.1 & $31.9-45.2$ & \multirow{2}{*}{0.23} \\
\hline & Male & 81 & 55.5 & 43.7 - 67.3 & 130 & 61.9 & $54.8-68.1$ & \\
\hline \multicolumn{2}{|l|}{ Age in years } & 146 & 69.9 & $68.0-71.1$ & 210 & 70.6 & $68.5-72.7$ & 0.62 \\
\hline \multicolumn{2}{|l|}{$\begin{array}{l}\text { Days PVC1 } \\
\text { Days PVC2 } \\
\text { Days PVC3 } \\
\text { Days PVC4 }\end{array}$} & 127 & 2.1 & $1.9-2.2$ & 184 & 2.5 & $2.3-2.7$ & $<0.001$ \\
\hline
\end{tabular}

m: mean

tribution, followed by a green PVC $(1.3 \mathrm{~mm})$ and then a yellow PVC $(0.7 \mathrm{~mm})$, and the difference was significant. PVCs with a smaller luminal diameter (e.g., blue, $0.9 \mathrm{~mm}$ ) were used less often and those with a larger luminal diameter (e.g., green, $1.3 \mathrm{~mm}$ ) were used more often in 2013 compared with 2008. Yellow PVCs $(0.7 \mathrm{~mm})$ were not used at all in 2013 compared with 2008. PVCs with larger luminal diameters were used more often in 2013 compared with 2008.

\section{Discussion}

Six-year follow-up of an improvement intervention in patients who received treatment for acute chest pain in a coronary care unit highlighted the benefits of avoiding unnecessary changes of PVCs. PVCs were replaced for clinical indications or every $72 \mathrm{~h}$. This result supports the work of Rickard et al., who use clinical indicators to 
decide if PVCs should be replaced or removed, as opposed to the usual prescribed length of time ( $\leq 72 \mathrm{~h})$, the PVC has been in situ [15]. The present study as well as that of Webster et al. show the benefits of avoiding unnecessary changes of PVCs, such as a reduction in: patient discomfort; equipment costs; staff workload [9] [15]. This knowledge should be taken into account given that PVC insertion often results in swelling and redness as early as $6 \mathrm{~h}$ after insertion [29]. However, inter-patient differences in reactions to PVCs mean that they should be inserted or changed only if it is indicated clinically and not according to a fixed schedule (72 h).

From a QI perspective, patients' knowledge of the symptoms and signs of thrombophlebitis is important. Lundgren et al. showed that residual symptoms of thrombophlebitis after PVC removal could be apparent $\leq 5$ months after hospital discharge [30]. Therefore, patients should be aware of the signs and symptoms associated with discharge from care: redness, swelling, increased temperature at site, palpable induration, fluid discharges, pain, and pain upon palpation. If two of these symptoms emerge based on the site where the PVC is removed, patients should contact the hospital for extra checks and treatment [3] [30].

During the period of the survey (2008-2013), a significant reduction in the prevalence of thrombophlebitis was noted in patients who had their PVC replaced as a result of clinical indications or every $72 \mathrm{~h}$. This treatment was a part of the improvement work implemented by all nurses on the ward (Table 3). This result is supported by prospective longitudinal studies showing that infections and the risk of superficial thrombophlebitis are highest in the first day after PVC insertion [4] [31]. Swedish guidelines have shown that PVCs should be inserted within the shortest possible time and be replaced every 24 - $72 \mathrm{~h}$ [26]. Data on the prevalence of thrombophlebitis if PVCs are re-sited 72 - $96 \mathrm{~h}$ after insertion or on clinical indications are lacking and there is no evidence of benefit to support current practice of changing PVC routinely every three to four days [12].

An improvement intervention must be evaluated through systematic collection of data to measure the effects of that intervention [32]. The number of days a PVC was left in situ to show a significant increase from 2008 to 2013 (Table 5) within prehospital care (PVC1) and on the ward (PVC 2-4). However, the prevalence of thrombophlebitis increased significantly within prehospital care but decreased significantly on the ward. These results may be related to a lack of planning of the improvement intervention from healthcare professionals [33]. A patient-centered perspective to improve clinical performance facilitates improvement interventions [34]. There is evidence on the consequences of involving only a single care process in improvement interventions [33]. Patient-centered thinking emphasizes a holistic view in the efforts of healthcare professionals for QI, and includes all the people involved in patient care [35]. Care of patients with acute chest pain involves at least two processes: prehospital and inpatient. Nurses on the ward are involved in the improvement intervention but the paramedics in the prehospital setting are not. These results may emphasize the need of involving healthcare professionals in each step of patient care. Therefore the method used in this QI captures the nurses perception of lack of experience as one of the root cause to thrombophlebitis [20].

Zingg et al. also found that if untrained or inexperienced healthcare workers insert PVCs, the risk of thrombophlebitis increases [36]. This phenomenon can probably not explain the increase in the prevalence of thrombophlebitis in our study because all paramedics were registered nurses in 2013 (though their level of experience was not known). The improvement intervention regarding evidence-based PVC treatment involved all nurses on the ward, and the improvement intervention was undertaken in several steps.

From 2008 to 2013, when paramedics inserted PVCs, a significant increase in the prevalence of thrombophlebitis ( $p=0.04)$ was noted (Table 4), a result that is in accordance with other studies [5] [37]. Swedish guidelines for paramedics state that all patients with acute chest pain should have the PVC inserted in the forearm to enable injection of vital agents. However, the expectation of "load and go" treatment of patients with chest pain in hospital could affect PVC handling. Preparing the patient for rapid transport could result in poor hygiene with respect to PVC insertion.

National and local guidelines recommend that paramedics should insert PVCs with luminal diameters of $\geq 1.1$ $\mathrm{mm}$ in patients with acute chest pain. Our results showed a significant reduction in use of PVCs of luminal diameter $0.7 \mathrm{~mm}$ and $0.9 \mathrm{~mm}$ to favor of $1.1 \mathrm{~mm}$. In 2008, PVCs with a luminal diameter of $1.1 \mathrm{~mm}$ were inserted in $63 \%$ of patients, whereas in 2013 it was $71 \%$, which should have reduced the risk of thrombophlebitis. Studies have shown that a smaller luminal diameter increases the risk of thrombophlebitis because small catheters allow more blood flow into adjacent tissues [3] [38]. Also, the material and lumen of catheters can increase the risk of thrombophlebitis [39]-[41].

Paramedics who instigated PVC-based treatment did so in significantly more upper-arm locations in 2008 and 2013 (Table 4). These results are not in accordance with recommendations that a PVC should be inserted in a 
Table 6. Medicines (i.v.) given by paramedics to treat chest pain.

\begin{tabular}{ll}
\hline \multicolumn{1}{c}{2008} & \multicolumn{1}{c}{2013} \\
\hline 1 Ketogan Novum ${ }^{\circledR}, 5 \mathrm{mg} / \mathrm{mL}$ & 1 Morphine ${ }^{\circledR}$ diluted to $1 \mathrm{mg} / \mathrm{mL}$ and not diluted to $10 \mathrm{mg} / \mathrm{mL}$ \\
${ }^{*}$ Ketobemidone & ${ }^{*}$ Morphine \\
2 Ringer-Acetat ${ }^{\circledR}$ & 2 Ringer-Acetat ${ }^{\circledR}$ \\
${ }^{*}$ Isotonic crystalloid solution & ${ }^{*}$ Isotonic crystalloid solution \\
3 Stesolid novum ${ }^{\circledR} 5 \mathrm{mg} / \mathrm{mL}$ & 3 Perfalgan ${ }^{\circledR} 10 \mathrm{mg} / \mathrm{mL}$ \\
${ }^{*}$ Diazepam & ${ }^{*}$ Paracetamol \\
4 Adrenalin ${ }^{\circledR} 0.1 \mathrm{mg} / \mathrm{mL}$ & 4 Stesolid novum ${ }^{\circledR} 5 \mathrm{mg} / \mathrm{mL}$ \\
${ }^{*}$ Adrenalin & ${ }^{*}$ Diazepam \\
5 Furix ${ }^{\circledR} 10 \mathrm{mg} / \mathrm{mL}$ & 5 Zofran ${ }^{\circledR} 2 \mathrm{mg} / \mathrm{mL}$ \\
${ }^{*}$ Furosemide & ${ }^{*}$ Ondansetron \\
\hline
\end{tabular}

${ }^{*}$ Genericname

larger vein (e.g. in the forearm) in patients suffering from chest pain [42]. This treatment could be one of the reasons why patients had a significantly higher prevalence of thrombophlebitis. In addition, the current must common treatment for acute chest pain increases the risk of thrombophlebitis. This treatment (Table 6) changed from 2008 to 2013 to increased use of morphine (i.v.) as first-line treatment for acute chest pain instead of ketobemidone; morphine may increase the risk of thrombophlebitis [29] [43].

Significant increases in the prevalence of thrombophlebitis could be explained by inappropriate disinfection of skin in conjunction with PVC-based treatment [42]. One reason could be the difficulties of working in an aseptic manner in the environment where the patient with acute chest pain is collected. This hypothesis is supported by the significantly lower prevalence of thrombophlebitis on the ward, where aseptic conditions can be controlled and improved. Studies have shown that appropriate aseptic conditions prevent thrombophlebitis [31] [40] [44].

\subsection{Methodological Considerations}

One of the strengths of our follow-up study was that we could record changes over time that may have been affected by new work practices [45]. However, these comparisons were made over time at the group level, so the same patients and staff were not compared. Also, we did not have information on the time of day patients received PVC-based treatment, or distribution of night-time and daytime patients in 2008 and 2013. Furthermore, frequencies in the tables for some options were low, which reduced the statistical power of our study [28].

\subsection{Clinical Implications}

QI on the ward showed a significant reduction in the prevalence of thrombophlebitis. These findings emphasize the value of using systematic daily inspections and checklists to achieve quality and safety in healthcare. In improvement interventions regarding PVC-based treatment, the impact that healthcare professionals in other units has on patient care must be considered. In addition, patients must be encouraged to take part in the follow-up of improvement interventions.

\section{Acknowledgements}

The authors acknowledge the support of the Department of Cardiology, County Hospital Ryhov, Jönköping, Sweden. We would also like to express gratitude to the Medical Research Council of Southeast Sweden (FORSS) for financial support.

\section{Disclosure}

There are no conflicts of interest to disclose.

\section{References}

[1] Cicolini, G., et al. (2009) Position of Peripheral Venous Cannulae and the Incidence of Thrombophlebitis: An Observational Study. Journal of Advanced Nursing, 65, 1268-1273. http://dx.doi.org/10.1111/j.1365-2648.2009.04980.x 
[2] Idvall, E. and Gunningberg, L. (2006) Evidence for Elective Replacement of Peripheral Intravenous Catheter to Prevent Thrombophlebitis: A Systematic Review. Journal of Advanced Nursing, 55, 715-722. http://dx.doi.org/10.1111/j.1365-2648.2006.03962.x

[3] Tagalakis, V., et al. (2002) The Epidemiology of Peripheral Vein Infusion Thrombophlebitis: A Critical Review. American Journal of Medicine, 113, 146-151. http://dx.doi.org/10.1016/S0002-9343(02)01163-4

[4] Curran, E.T., et al. (2000) Multi-Centre Research Surveillance Project to Reduce Infections/Phlebitis Associated with Peripheral Vascular Catheters. Journal of Hospital Infection, 46, 194-202. http://dx.doi.org/10.1016/s0195-6701(00)90831-4

[5] Goransson, K.E. and Johansson, E. (2012) Prehospital Peripheral Venous Catheters: A Prospective Study of Patient Complications. The Journal of Vascular Access, 13, 16-21. http://dx.doi.org/10.5301/JVA.2011.8418

[6] Anderson, A.D., Palmer, D. and MacFie, J. (2003) Peripheral Parenteral Nutrition. British Journal of Surgery, 90, 1048-1054. http://dx.doi.org/10.1002/bjs.4328

[7] Gowardman, J.R., Lipman, J. and Rickard, C.M. (2010) Assessment of Peripheral Arterial Catheters as a Source of Sepsis in the Critically Ill: A Narrative Review. Journal of Hospital Infection, 75, 12-18. http://dx.doi.org/10.1016/j.jhin.2010.01.005

[8] Rickard, C.M., et al. (2010) Routine Resite of Peripheral Intravenous Devices Every 3 Days Did Not Reduce Complications Compared with Clinically Indicated Resite: A Randomised Controlled Trial. BMC Medicine, 8, 53. http://dx.doi.org/10.1186/1741-7015-8-53

[9] Webster, J., et al. (2007) Developing a Research Base for Intravenous Peripheral Cannula Re-Sites (DRIP Trial). A Randomised Controlled Trial of Hospital In-Patients. International Journal of Nursing Studies, 44, 664-671. http://dx.doi.org/10.1016/j.ijnurstu.2006.02.003

[10] Forslöw, M. (2015) Peripheral Vascular Catheters (in Swedish). Competence Description for Registered Nurses.

[11] Lee, W.L., Chen, H.-L., Tsai, T.-Y., Lai, I.-C., Chang, W.-C., Huang, C.-H. and Fang, C.-T. (2009) Risk Factors for Peripheral Intravenous Catheter Infection in Hospitalized Patients: A Prospective Study of 3165 Patients. American Journal of Infection Control, 37, 683-686. http://dx.doi.org/10.1016/j.ajic.2009.02.009

[12] Webster, J., Osborne, S., Rickard, C.M. and New, K. (2015) Clinically-Indicated Replacement versus Routine Replacement of Peripheral Venous Catheters. Cochrane Database of Systematic Reviews, No. 8, Article No.: CD007798. http://dx.doi.org/10.1002/14651858.cd007798.pub4

[13] Kommentar, S. (2013) Perifer Venkateter (PVK)—Regular Changing or Replacing in Clinical Indication? SBU Rapport. (In Swedish) http://www.sbu.se/upload/SBU_kommenterar/Perifer_venkateter.pdf

[14] Lai, K.K. (1998) Safety of Prolonging Peripheral Cannula and IV Tubing Use from 72 Hours to 96 Hours. American Journal of Infection Control, 26, 66-70. http://dx.doi.org/10.1016/S0196-6553(98)70063-X

[15] Rickard, C.M., Webster, J., Wallis, M.C., Marsh, N., McGrail, M.R., French, V., et al. (2012) Routine versus Clinically Indicated Replacement of Peripheral Intravenous Catheters: A Randomised Controlled Equivalence Trial. Lancet, 380, 1066-1074. http://dx.doi.org/10.1016/S0140-6736(12)61082-4

[16] Idvall, E. (2013) Quality Indicators in Nursing: Swedish Society of Nursing. 6th Edition, Gothia Education, Gothenburg.

[17] Batalden, P.B. and Davidoff, F. (2007) What Is “Quality Improvement” and How Can It Transform Healthcare? Quality and Safety in Health Care, 16, 2-3. http://dx.doi.org/10.1136/qshc.2006.022046

[18] Vincent, C.A. (2003) Understanding and Responding to Adverse Events. The New England Journal of Medicine, 348, 1051-1056. http://dx.doi.org/10.1056/NEJMhpr020760

[19] Lynn, J., Baily, M.A., Bottrell, M., Jennings, B., Levine, R.J., Davidoff, F., et al. (2007) The Ethics of Using Quality Improvement Methods in Health Care. Archives of Internal Medicine, 146, 666-673. http://dx.doi.org/10.7326/0003-4819-146-9-200705010-00155

[20] Vincent, C.A. (2004) Analysis of Clinical Incidents: A Window on the System Not a Search for Root Causes. Quality and Safety in Health Care, 13, 242-243. http://dx.doi.org/10.1136/qshc.2004.010454

[21] Connelly, L.M. (2012) Root Cause Analysis. Medsurg Nursing, 21, 316-313.

[22] Lambton, J. and Mahlmeister, L. (2010) Conducting Root Cause Analysis with Nursing Students: Best Practice in Nursing Education. Journal of Nursing Education, 49, 444-448. http://dx.doi.org/10.1136/qshc.2004.010454

[23] Ovretveit, J.C., Shekelle, P.G., Dy, S.M., McDonald, K.M., Hempel, S., Pronovost, P., Rubenstein, L., Taylor, S.L., Foy, R. and Wachter, R.M. (2011) How Does Context Affect Interventions to Improve Patient Safety? An Assessment of Evidence from Studies of Five Patient Safety Practices and Proposals for Research. BMJ Quality and Safety, 20, 604-610. http://dx.doi.org/10.1136/bmjqs.2010.047035

[24] Scott, I. (2009) What Are the Most Effective Strategies for Improving Quality and Safety of Health Care? Internal 
Medicine Journal, 39, 389-400. http://dx.doi.org/10.1111/j.1445-5994.2008.01798.x

[25] Davidoff, F. and Batalden, P. (2005) Toward Stronger Evidence on Quality Improvement. Draft Publication Guidelines: The Beginning of a Consensus Project. Quality and Safety in Health Care, 14, 319-325. http://dx.doi.org/10.1136/qshc.2005.014787

[26] The Swedish National Board of Health and Welfare (SBU) (2005) SBU Regular Replacement of Peripheral Venous Catheter (PVK) to Prevent Tromboflibit. SBU Alert-rapport nr 2005-05. (In Swedish)

[27] Unit, T.W.M.A.E. (2008) World Medical Association Declaration of Helsinki. http://www.wma.net/en/30publications/10policies/b3/17c.pdf

[28] Krikwood, B.R. and Sterne, J.A.C. (2005) Essential Medical Statistics. Second Edition, Blackwell, Hoboken.

[29] Adolfsson, A. and Luttropp, H.H. (1996) Venous Catheterization Can Cause Infusion Thrombophlebitis. Study of the Literature on Its Causes and Occurrence. Lakartidningen, 93, 4403-4404.

[30] Lundgren, A., Jorfeldt, L. and Ek, A.C. (1993) The Care and Handling of Peripheral Intravenous Cannulae on 60 Surgery and Internal Medicine Patients: An Observation Study. Journal of Advanced Nursing, 18, 963-971. http://dx.doi.org/10.1046/j.1365-2648.1993.18060963.x

[31] Hirschmann, H., Fux, L., Podusel, J., Schindler, K., Kundi, M., Rotter, M., et al. (2001) The Influence of Hand Hygiene Prior to Insertion of Peripheral Venous Catheters on the Frequency of Complications. Journal of Hospital Infection, 49, 199-203. http://dx.doi.org/10.1053/jhin.2001.1077

[32] Walshe, K. (2009) Pseudoinnovation: The Development and Spread of Healthcare Quality Improvement Methodologies. International Journal for Quality in Health Care, 21, 153-159. http://dx.doi.org/10.1093/intqhc/mzp012

[33] Joosten, T., Bongers, I. and Janssen, R. (2009) Application of Lean Thinking to Health Care: Issues and Observations. International Journal for Quality in Health Care, 21, 341-347. http://dx.doi.org/10.1093/intqhc/mzp036

[34] Nygardh, A., Malm, D., Wikby, K. and Ahlström, G. (2012) The Experience of Empowerment in the Patient-Staff Encounter: The Patient's Perspective. Journal of Clinical Nursing, 21, 897-904. http://dx.doi.org/10.1111/j.1365-2702.2011.03901.x

[35] Sujan, M. and Furniss, D. (2015) Organisational Reporting and Learning Systems: Innovating Inside and Outside of the Box. Clinical Risk, 21, 7-12. http://dx.doi.org/10.1177/1356262215574203

[36] Zingg, W. and Pittet, D. (2009) Peripheral Venous Catheters: An Under-Evaluated Problem. International Journal of Antimicrobial Agents, 34, 38-42. http://dx.doi.org/10.1016/S0924-8579(09)70565-5

[37] Kampf, G., Reise, G., James, C., Gittelbauer, K., Gosch, J. and Alpers, B. (2013) Improving Patient Safety during Insertion of Peripheral Venous Catheters: An Observational Intervention Study. GMS Hygiene and Infection Control, 8, Doc18.

[38] Macklin, D. (2003) Phlebitis: A Painful Complication of Peripheral IV Catheterization That May Be Prevented. American Journal of Nursing, 103, 55-60. http://dx.doi.org/10.1097/00000446-200302000-00027

[39] Uslusoy, E. and Mete, S. (2008) Predisposing Factors to Phlebitis in Patients with Peripheral Intravenous Catheters: A Descriptive Study. Journal of the American Academy of Nurse Practitioners, 20, 172-180. http://dx.doi.org/10.1111/j.1745-7599.2008.00305.x

[40] Karadag, A. and Gorgulu, S. (2000) Effect of Two Different Short Peripheral Catheter Materials on Phlebitis Development. Journal of Intravenous Nursing, 23, 158-166.

[41] Hasselberg, D., Ivarsson, B., Andersson, R. and Tingstedt, B. (2010) The Handling of Peripheral Venous CathetersFrom Non-Compliance to Evidence-Based Needs. Journal of Clinical Nursing, 19, 3358-3363. http://dx.doi.org/10.1111/j.1365-2702.2010.03410.x

[42] O’Grady, N.P., Alexander, M., Burns, L.A., Dellinger, E.P., Garland, J., Heard, S.O., et al. (2011) Summary of Recommendations: Guidelines for the Prevention of Intravascular Catheter-Related Infections. Clinical Infectious Diseases, 52, 1087-1099. http://dx.doi.org/10.1093/cid/cir138

[43] eHealthMe (2014) Could Your Drug Cause Phlebitis? http://www.ehealthme.com/symptom/phlebitis

[44] Creedon, S.A. (2005) Healthcare Workers' Hand Decontamination Practices: Compliance with Recommended Guidelines. Journal of Advanced Nursing, 51, 208-216. http://dx.doi.org/10.1111/j.1365-2648.2005.03490.x

[45] Denise, F.P. and Beck, C.T. (2008) Nursing Research: Generating and Assessing Evidence for Nursing Practice. Lippincott Williams \& Wilkins, Philadelphia. 